\title{
STRATEGY AS THE CONDITION OF PROCESS MATURITY OF PUBLIC ADMINISTRATION UNITS
}

\author{
Magdalena RACZYŃSKA ${ }^{1^{*}}$, Krzysztof KRUKOWSKI ${ }^{2}$ \\ ${ }^{1}$ University of Warmia and Mazury in Olsztyn, Poland; magda.raczynska@uwm.edu.pl, \\ ORCID: 0000-0002-4961-5028 \\ ${ }^{2}$ University of Warmia and Mazury in Olsztyn, Poland; kkruk@uwm.edu.pl, ORCID: 0000-0002-1614-4397 \\ * Correspondence author
}

Purpose: The aim of the research presented in the article was to identify factors related to strategy, that condition implementing and developing process approach in the community offices from the Warmian-Masurian voivodship.

Design/methodology/approach: In order to acknowledge these factors, surveys among the chosen employees of the community offices were carried out.

Findings: As results from the conducted study, factors that are perceived as necessary for implementing and developing the process approach in the researched entities are: knowledge of the mission, vision and strategic objectives of the community among the employees of the office; ongoing monitoring of the needs and requirements of the community's inhabitants; adjusting the office's resources to changes in the environment and referring to the community's mission and strategic goals when making decisions by management.

Originality/value: The results of the research obtained can support the managerial decisions made by public managers related to the introduction and development of the discussed concept in public organizations.

Keywords: public administration unit, community office, process maturity, process approach, strategy.

Category of the paper: Research paper.

\section{Introduction}

Process management (process approach) is a concept that was initially introduced in business organizations. However, after the success of its use in the private sector, this approach was also implemented in managing public organizations (beginning of the 1990s) (Reyes, 1998). The first studies on process management in public organizations (public administration units) include works by authors such as: G. Bouckaert, A. Halachmi (Bouckaert and Halachmi, 1995); R. Linden (Linden, 1993); T. Packwood (Packwood et al., 1998) or L.P. Willcocks 
(Willcocks et al., 1997). It is worth mentioning that the introduction of the process approach in public administration units can be based on the New Public Management model (Opolski and Modzelewski, 2004).

An important area of research on the use of process management concept in organizations is the identification of the level of their process maturity. This also applies to the process solutions (process-based solutions) implemented in individual public administration units.

Among the authors who develop issues related to the concept of organizations' process maturity are M. Rosemann and T. de Bruin. They perceive process maturity as a certain awareness that an organization is formed by horizontally occurring processes that should be managed in an appropriate manner, so that both processes and the entire organization systematically provide ever-better results of operations (Rosemann and de Bruin, 2005). According to M. Rosemann and T. de Bruin, process maturity can also be defined as a combination of the "coverage" and "proficiency" of an organization. Coverage refers to organization's ability and level of implementation of process management, while proficiency measures the quality and effectiveness of implementing processes in an organization. To assess the process maturity of an organization through these factors, a set of criteria is used to help identify organizations that reach low or high-level in the use of process-based solutions (Rosemann and de Bruin, 2005).

For the purpose of the article, process maturity is understood as the implementation and development of the process approach in organizations.

Ensuring a high level of efficiency when implementing and developing process-based solutions for the management systems of organizations, including public ones, requires identifying the internal potential of these actions. In the case of public administration units, this potential is conditioned by factors occurring, among others, in such areas of an organization as: strategy, organizational structure, motivations and attitudes of employees, finances, processes of provided services or solutions in the field of information technologies (IT).

The aim of the research presented in the article was to identify factors related to strategy, that condition implementing and developing the process management concept in the community offices in the Warmian-Masurian voivodship.

\section{Literature background}

The literature of the subject does not abound in a multitude of works showing the interdependence issues of implementation and development of the process approach and the organization's strategy, while among the authors who raise these issues, one can find views usually formulated at a high level of generality. For example, A. Bitkowska, K. Kolterman, G. Wójcik and K. Wójcik emphasize that: "(...) one of the main assumptions of the process 
approach is that it should allow for achieving strategic effects" (Bitkowska et al., 2011, p. 18). According to G. Jokiel, this situation is related to the fact that integrated management of the process system in a given organization results in adapting it to the organization's strategy (Jokiel, 2009). R. Brajer-Marczak emphasizes that process maturity indicates how perception of processes becomes a part of the organization's strategy (Brajer-Marczak, 2012). And, on the one hand, the level of process maturity of a given organization informs about the awareness of employees in terms of their participation in processes, and, on the other hand, how the managers use the knowledge about processes in organizational development decisions. Organization's ability to effectively manage processes supporting the implementation of strategic objectives indicates the existence of a dual dependency - firstly, the objectives of processes must result from strategic goals, and secondly, achieving the planned goals of processes should enable implementation of the strategy. Derivation of process objectives against strategic goals was also indicated by, among others, G.A. Rummler and A.P. Brache, M. Hammer, R. Talwar, R.L. Manganelli and M.M. Klein or R.S. Kaplan and D.P. Norton (Kraśniak, 2009), while C.B. Adair and B.A. Murray also point to the need to relate key processes to the vision of the organization (Adair and Murray, 2002). W. Bandara, M. Indulska, S. Chong and S. Sadiq recognize that one of the most important aspects of achieving full process maturity by organizations is the proactive introduction of the process approach, reflected, among others, in the principles adopted in the strategy (Bandara et al., 2007). In the presented views, the common point is to include process management as an element that should be adapted to the strategy implemented in the organization. H.G. Adamkiewicz-Drwiłło in her deliberations goes even a step further, considering that any attempt to determine the level of competitiveness, whether operational or strategic, is possible when an organization is captured in a process perspective (Adamkiewicz-Drwiłło, 2009). It can therefore be concluded that process approach is a prerequisite for efficient strategic management.

The existence of dependencies between organization's strategy and the process maturity is reflected in the developed process maturity models. Among model proposals that point to strategic elements as determinants of implementing and developing process management concept in organizations, one can indicate e.g. the D. Fisher's model (Fisher, 2004). This author presents process maturity in terms of five states, in which the strategy area is considered one of the "five levers of change", in addition to the control system, processes, employees or IT occurring in an organization. In this particular model, the strategy is captured through the prism of organizational response to changes in market conditions, the level of integration with external partners, and the degree of organization's concentration on processes. Also J. Zwicker, P. Fettke and P. Loos proposed a process maturity model showing the concept of process maturity based on five levels, but specifically dedicated to public organizations (Zwicker et al., 2010). Qualification to a given level is conditional on meeting the criteria, which are also grouped in five areas. One of these areas is the strategy that is described through two criteria: defining a goal and defining objective values. 


\section{Methodology}

In order to identify factors from the area of strategy, which influence process maturity of community offices (offices), surveys were carried out. The constructed questionnaire included questions regarding the assessment of individual determinants of the process maturity of the offices, where the strategy area was one of its elements (along with IT, organizational culture, processes and HR potential, leadership and work organization). In the area of strategy, the questionnaire contained 14 specific factors referring to: coordination of process objectives with the objectives included in the community development strategy; adjusting the organizational structure of the office to changes in the community development strategy; knowledge of mission, vision and strategic objectives of the community, as well as the degree of studies on what the needs of the community's inhabitants are and the modifications in its development strategy undertaken in this respect. These factors were assessed in the five-point Likert scale described numerically and verbally ${ }^{1}$. The respondent in each community office was a person holding the position of office's secretary and a person indicated by the secretary who, in his or her opinion, showed experience in the implementation or development of the process approach at the office. When choosing the secretary for the respondent, he or she was guided by their position in the organizational structure of the community office, as well as the scope of duties, often requiring extensive knowledge about, among others: community office functioning, applied methods and management concepts in the office, the subject of individual cells in the organizational structure of the office or legal acts regulating its work.

The research was carried out from June to October 2017. The questionnaire was sent to respondents by post or delivered personally to the community office.

The survey covered the entire population of community offices in the Warmian-Masurian voivodship, i.e. 116 offices, including: 16 urban community offices $(13.8 \%$ of the total population), 33 urban-rural community offices (28.5\% of the total population) and 67 rural community offices $(57.7 \%$ of the population). The final sample consisted of 97 community offices $^{2}$. The majority of entities in the research sample were the rural offices $(55.7 \%)$. The second position was occupied by the urban-rural offices $(28.9 \%)$, and the least numerous groups of offices were the entities representing the urban communities of the WarmianMasurian voivodship (15.4\%).

\footnotetext{
${ }^{1}$ Respondents were able to assess the extent to which individual factors matter, in their opinion, when implementing or developing process management concept in the community office, where: 1 - does not matter, 2 - matters to a small extent, 3 - matters to a medium extent, 4 - is of big importance, 5 - is always necessary.

${ }^{2}$ In total, responses of varying degrees of completeness were obtained from 99 community offices (198 completed questionnaires), obtaining a return of $85 \%$. However, 194 returned questionnaires were selected for further analysis - 97 pairs from individual offices. Thus, the final number of respondents was 194.
} 
The obtained empirical material from the selected questionnaires was entered into the electronic database and subjected to the analysis process, including testing the reliability of the research tool using the Cronbach's alpha coefficient. This indicator for the strategy area amounted to 0.89 .

\section{Research results}

In order to verify whether any differences occurred between different types of the researched offices in the assessment of factors from the area of strategy as a condition of process maturity of these entities, a one-way analysis of variance (ANOVA) for independent samples was carried out (Table 1). The value of the factor $\mathrm{F}$ indicates that the test is statistically significant at the level of $p<0.05$. And the magnitude of the effect $\eta^{2}$ confirms the existence of statistically significant differences between respondents from urban, urban-rural and rural community offices in the assessment of factors from the strategy area as a condition for process maturity of these entities.

Table 1.

The result of a one-way analysis of variance for independent samples

\begin{tabular}{|c|c|c|c|c|c|c|c|c|}
\hline Dependent variable & $\begin{array}{c}\text { Type of a } \\
\text { community office }\end{array}$ & $\mathbf{M}$ & SD & LL & UL & $\boldsymbol{F}$ & $\boldsymbol{p}$ & $\boldsymbol{\eta}^{\mathbf{2}}$ \\
\hline \multirow{2}{*}{ Strategy } & urban & 3.46 & 0.12 & 3.23 & 3.7 & 5.43 & $0.005^{*}$ & 0.05 \\
\cline { 2 - 9 } & urban-rural & 3.08 & 0.09 & 2.9 & 3.25 & & & \\
& rural & 3.02 & 0.06 & 2.89 & 3.14 & & & \\
\hline
\end{tabular}

${ }^{*} p<0,05$.

Where: $\mathrm{M}$ - mean, $\mathrm{SD}$ - standard deviation, LL - lower limit of the $95 \%$ confidence interval, UL - upper limit of the $95 \%$ confidence interval, $F$ - result of the Fisher test, $p$ - statistical significance, $\eta^{2}$ - effect size.

Source: Own work based on research results.

In addition, it can be noted that the average answers (mean) provided by the respondents were always higher in the urban community offices than in the urban-rural and rural ones. Also, the respondents from the urban-rural offices gave, on average, higher answers than the respondents from the offices of rural type.

The percentage representation of respondents' responses is presented in table 2 . In the description of the results, the assumption was made, that for classifying specific factor from the strategy area as relevant in the implementation and development of the process approach in the surveyed entities, the sum of the share of responses "is of big importance" and "is always necessary" for this factor needs to be higher than $50 \%$. 
In the made analysis, eight factors related to the strategy considered relevant in introducing and developing a process approach in the urban community offices and four factors in the urbanrural and rural ones were specified ${ }^{3}$.

Table 2.

Frequency of indications of specific factors from the strategy area as determinants of process maturity at the community offices in the Warmian-Masurian voivodship (in \%)

\begin{tabular}{|c|c|c|c|c|c|c|c|c|c|c|c|c|c|c|c|}
\hline \multirow[t]{4}{*}{ F. } & \multicolumn{15}{|c|}{ Type of the community office } \\
\hline & \multicolumn{5}{|c|}{ urban } & \multicolumn{5}{|c|}{ urban-rural } & \multicolumn{5}{|c|}{ rural } \\
\hline & \multicolumn{5}{|c|}{ given answers } & \multicolumn{5}{|c|}{ given answers } & \multicolumn{5}{|c|}{ given answers } \\
\hline & 1 & 2 & 3 & 4 & 5 & 1 & 2 & 3 & 4 & 5 & 1 & 2 & 3 & 4 & 5 \\
\hline $\mathrm{S} 1$ & - & 6.7 & 16.7 & 46.6 & 30 & - & 7.1 & 39.3 & 39.3 & 14.3 & - & 5.6 & 37.9 & 38.9 & 17.6 \\
\hline $\mathrm{S} 2$ & - & - & 13.3 & 53.4 & 33.3 & - & 10.7 & 37.5 & 30.4 & 21.4 & 1.8 & 11.1 & 35.2 & 35.2 & 16.7 \\
\hline S3 & 20 & 13.3 & 33.3 & 3.4 & 30 & 16.1 & 21.4 & 26.8 & 23.2 & 12.5 & 14.8 & 32.4 & 27.8 & 17.6 & 7.4 \\
\hline $\mathrm{S} 4$ & 13.3 & 13.3 & 23.4 & 33.3 & 16.7 & 5.4 & 25 & 33.9 & 26.8 & 8.9 & 8.3 & 21.3 & 33.3 & 27.8 & 9.3 \\
\hline S5 & 6.7 & 3.3 & 30 & 10 & 50 & - & 16.1 & 41.1 & 32.1 & 10.7 & 6.5 & 15.7 & 43.5 & 28.7 & 5.6 \\
\hline S6 & - & 10 & 23.3 & 20 & 46.7 & 5.4 & 14.3 & 44.6 & 30.3 & 5.4 & 4.6 & 15.7 & 45.4 & 26.9 & 7.4 \\
\hline S7 & - & 13.3 & 23.4 & 30 & $\begin{array}{l}33.3 \\
\end{array}$ & 3.6 & 14.3 & 42.8 & 17.9 & 21.4 & 5.6 & 15.7 & 35.2 & 30.6 & 12.9 \\
\hline $\mathrm{S} 8$ & - & 3.3 & 13.3 & 70.1 & 13.3 & 5.4 & 7.1 & 28.5 & 41.1 & 17.9 & - & 13.9 & 32.4 & 36.1 & 17.6 \\
\hline S9 & - & 10 & 26.7 & 30 & 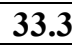 & 7.2 & 10.7 & 33.9 & 32.1 & 16.1 & 7.4 & 23.2 & 27.8 & 26.8 & 14.8 \\
\hline S10 & - & - & 26.7 & 23.3 & 50 & - & 7.1 & 30.4 & 41.1 & 21.4 & 4.6 & 7.4 & 26.9 & 48.1 & 13 \\
\hline S11 & 6.7 & 23.3 & 30 & 33.3 & 6.7 & 8.9 & 23.2 & 42.9 & 17.9 & 7.1 & 7.4 & 21.3 & 38 & 25.9 & 7.4 \\
\hline S12 & 70 & 20 & 10 & - & - & 69.6 & 16.1 & 8.9 & 5.4 & - & 71.3 & 10.2 & 13.9 & 1.8 & 2.8 \\
\hline S13 & 46.7 & 20 & - & 20 & 13.3 & 64.3 & 19.6 & 14.3 & 1.8 & - & 63.9 & 12.9 & 14.8 & 5.6 & 2.8 \\
\hline S14 & 10 & 20 & 23.3 & 26.7 & 20 & 3.6 & 25 & 35.7 & 21.4 & 14.3 & 3.7 & 28.7 & 36.1 & 26.9 & 4.6 \\
\hline
\end{tabular}

Where: $\mathrm{F}$ - factor; 1 - does not matter, 2 - matters to a small extent, 3 - matters to a medium extent, 4 - is of big importance, 5 - is always necessary; S1 - Knowledge of the mission, vision and strategic objectives of the community among the employees of the office, S2 - Ongoing monitoring of the needs and requirements of the community's inhabitants (e.g. through public consultations, participatory budget, etc.), S3 - A cyclical survey of the satisfaction level of the community's inhabitants with the quality of services provided, S4 - Introducing modifications to the community development strategy in response to changes in the needs, requirements and level of satisfaction of the community's inhabitants from the quality of services provided, S5 - Integration of external partners into the planning and implementation process of the community development strategy, S6 - Monitoring and periodic evaluation of the implementation of the community development strategy, S7 - Providing up-to-date information on the implementation of tasks resulting from the strategy for the inhabitants of the community and the employees of the office, S8 - Adjusting the office's resources (including personnel, financial, information) to changes in the environment, S9 - Adjusting the office's organizational structure to changes in the community development strategy, S10 - Referring to the community's mission and strategic goals when making decisions by management, S11 - Conducting a systematic analysis of the activities of other community offices, which may be considered as exemplary, S12 - Using the Balanced Scorecard, S13 - Using tools like e.g. CAF, EFQM or PRI when conducting the office's self-assessment, identifying areas for improvement and introducing management improvements, S14 - Coordinating the objectives of the processes carried out in the office with the objectives included in the community development strategy.

Source: Own work based on research results.

The factors considered important by respondents from all types of offices during the actions mentioned were: knowledge of the mission, vision and strategic objectives of the community among the employees of the office; ongoing monitoring of the needs and requirements of the community's inhabitants (e.g. through public consultations, participatory budget, etc.); adjusting the office's resources (including personnel, financial, information) to changes in the environment and referring to the community's mission and strategic goals when making

\footnotetext{
${ }^{3}$ They were highlighted using bold font.
} 
decisions by management. It can be noticed that when taking into consideration all the abovementioned factors, their assessment reached a higher level in the case of respondents from the urban offices than in the case of the representatives of other types of the researched entities.

Among the factors assessed as important only by the respondents from the urban offices were: integration of external partners into the planning and implementation process of the community development strategy; monitoring and periodic evaluation of the implementation of the community development strategy; providing up-to-date information on the implementation of tasks resulting from the strategy for the inhabitants of the community and the employees of the office and adjusting the office's organizational structure to changes in the community development strategy. On the other hand, factors that, according to the indications of the persons participating in the study, can be considered as having no or a minor impact on the process maturity of the researched offices were: a cyclical survey of the satisfaction level of the community's inhabitants with the quality of services provided; introducing modifications to the community development strategy in response to changes in the needs, requirements and level of satisfaction of the community's inhabitants from the quality of services provided; conducting a systematic analysis of the activities of other community offices, which may be considered as exemplary; using tools like e.g. CAF, EFQM or PRI when conducting the office's selfassessment, identifying areas for improvement and introducing management improvements; coordinating the objectives of the processes carried out in the office with the objectives included in the community development strategy and using the Balanced Scorecard.

Similarities and differences when assessing the importance of factors from the strategy area in the implementation and development of the process approach in the community offices in Warmian-Masurian voivodship, depending on their type, are presented in Figure 1.

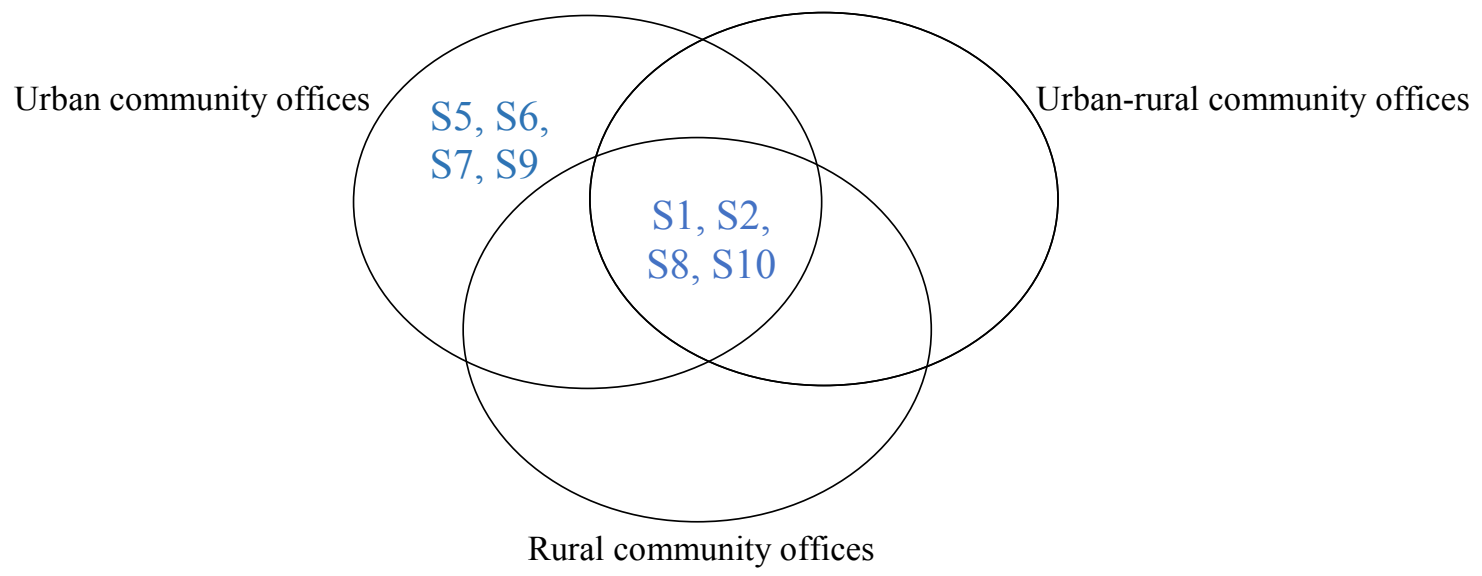

Figure 1. Similarities and differences in the assessment of the impact of factors in the area of strategy on the process maturity of the commune offices in Warmian-Masurian voivodship. Source: Own work based on research results. 


\section{Discussion}

The research showed that in the opinion of respondents it is possible to distinguish factors from the area of strategy that have a particular impact on the process maturity of the community offices in Warmian-Masurian voivodship. As indicated, one of these factors was the ongoing monitoring of the needs and requirements of the community's inhabitants. It may be related to the fact that familiarization with the often specific and changing expectations of citizens potentially affects the creation of new public services (and thus - the new processes), but also the continuous improvement of existing ones. On the basis of the conducted study, however, it is difficult to assess whether the information obtained from the process of monitoring the needs and requirements of the community's inhabitants is reflected in management decisions in the surveyed entities. The respondents also indicated, among others, the knowledge of the mission, vision and strategic goals of the community as a factor of big importance when implementing and developing process approach in the offices. And indeed, this factor can be treated as a stimulant of the process maturity of the community offices. This is because the correctness of identifying and improving processes aimed at satisfying the needs of public service recipients depends on the employees' knowledge of strategic goals. It can also be clearly stated that the knowledge in the field of strategy possessed by the management of offices affects the making of decisions regarding the implementation of the process approach.

On the other hand, the respondents assessed as non-existing or minor the potential of as many as six factors from the strategy area as elements stimulating the introduction and development of a process approach in the audited offices. According to the authors, however, at least some of these elements can be considered as important. It can be stated that not only the needs of public service recipients should be regularly monitored, but also the community's inhabitants' satisfaction with the level of services provided. And the actual information from these verifications should be used to make changes in the processes of services and in the community development strategy. Moreover, respondents do not appreciate the importance of tools such as CAF, EFQM, PRI or Balanced Scorecard in increasing the process maturity of community offices. However, this may be due to restrictions (e.g. financial, competence) of using these tools in community offices in the analysed voivodship. It can also be assumed as puzzling that the respondents underestimate the importance of the connection of process objectives with the objectives formulated in the community development strategy. In the face of stressing the role of this factor in the literature, the obtained results may indicate low knowledge of respondents in the area of the process approach.

It is worth considering stronger recognition of more factors from the strategy area seen as relevant in increasing the community offices' process maturity by respondents from the entities of urban type than from other types. This may be due to the fact that in the urban community offices usually more strategic tools are used and thus the respondents representing these offices 
have greater awareness of the impact of these elements on the implementation and development of the process approach.

\section{Conclusion}

The strategy as a factor influencing the implementation and increasing the scope of the process approach in organizations, including public administration units, is largely determined by organizational abilities of the management of a given office. It is the knowledge and experience of people managing community offices that influences, for example, to what extent the unit they manage will focus on the needs of public services recipients, and whether their constantly evolving needs translate into actual office management and are reflected in the community development strategy.

As results from the conducted research, factors from the strategy area that, in respondents' opinion, are relevant when introducing and developing the process approach in the community offices in Warmian-Masurian voivodship are, among others, those related to monitoring the needs and requirements of inhabitants, as well as to the knowledge of the community's mission, vision and strategic objectives among office employees and translating them into management decisions. Those of less or minor importance are factors related to the use of the information from monitoring and measuring the needs and the satisfaction of the community's inhabitants when implementing changes in the community development, but also to the use of tools designed to enable office self-assessment, identifying areas for improvement and introducing management improvements, or linking process objectives to objectives included in the community development strategy.

The limited research sample and limited knowledge of respondents in the field of process management applied in the examined offices can be considered as the basic limitations of the research presented in this study. Therefore, further research can be extended to all community offices in Poland.

\section{References}

1. Adair, C.B., and Murray B.A. (2002). Radykalna reorganizacja firmy. Warszawa: PWN.

2. Adamkiewicz-Drwiłło, H.G. (2009). Konkurencyjność operacyjna i strategiczna współczesnego przedsiębiorstwa - organizacji procesowej. Prace naukowe Uniwersytetu Ekonomicznego we Wrocławiu, 52, 357-365. 
3. Bandara, W., and Indulska, M., and Chong, S., and Sadiq S. (2007). Major Issues in Business Process Management: An Expert Perspective. Proceedings ECIS 2007 - The $15^{\text {th }}$ European Conference on Information Systems, 1240-1251. Retrieved from https://eprints.qut.edu.au/14345/1/14345.pdf, 10.05.2019.

4. Bitkowska, A., and Kolterman, K., and Wójcik, G., and Wójcik, K. (2011). Zarządzanie procesami w przedsiębiorstwie. Warszawa: Difin.

5. Bouckaert, G., and Halachmi, A. (1995). Re-engineering in the public sector. International Review of Administrative Sciences, 61(3), 323-327. doi: https://doi.org/10.1177/ 002085239506100301

6. Brajer-Marczak, R. (2012). Efektywność organizacji z perspektywy modelu dojrzałości procesowej. Zarzadzanie i Finanse, 10(1), 513-523.

7. Fisher, D.M. (2004). The Business Process Maturity Model. A Practical Approach for Identifying Opportunities for Organization. BPTrends, 1-7. Retrieved from https://www.bptrends.com/publicationfiles/10-04\%20ART\%20BP\%20Maturity\%20 Model\%20-\%20Fisher.pdf, 10.05.2019.

8. Jokiel, G. (2009). Podejście procesowe w zarządzaniu - geneza i kierunki rozwoju koncepcji. Prace Naukowe Uniwersytetu Ekonomicznego we Wroctawiu, 52, 15-22.

9. Kraśniak, J. (2009). Uwarunkowania sytuacyjno-organizacyjne wdrażania organizacji procesowej. Prace Naukowe Uniwersytetu Ekonomicznego we Wrocławiu, 52, 389-395.

10. Linden, R. (1993). Business Process Reengineering: Newest Fad, or Revolution in Government. Public Management, 75(11), 8-12.

11. Opolski, K., and Modzelewski, P. (2004). Zarządzanie jakościa w ustugach publicznych. Warszawa: CeDeWu.

12. Packwood, T., and Pollitt, C., and Roberts, S. (1998). Good medicine? a case study of business reengineering in a hospital. Policy and Politics, 26(4), 401-415. doi: https://doi.org/10.1332/030557398782106970.

13. Reyes, D.R. (1998). Public Sector Reengineering: Practice, Problems and Prospects. Asian Review Public Administration, 42(3-4), 184-202.

14. Rosemann, M., and de Bruin, T. (2005). Towards a business process maturity model. In: D. Bartmann, and F. Rajola, and J. Kallinikos, and D. Avison, and R. Winter, and P. Ein-Dor (Eds.), ECIS 2005 Proceedings of the Thirteenth European Conference on Information Systems. Regensburg. Retrieved from: https://eprints.qut.edu.au/25194/, 10.05.2019.

15. Willcocks, L.P., and Currie, W., and Jackson, S. (1997). In Pursuit of the Re-engineering Agenda in Public Administration. Public Administration, 75(4), 617-649. doi: https://doi.org/10.1111/1467-9299.00078.

16. Zwicker, J. and Fettke, P., and Loos, P. (2010). Business Process Maturity in Public Administrations. In: J. vom Brocke, and M. Rosemann (Eds.), Handbook on Business Process Management, 2 (pp. 369-395). Berlin-Heidelberg: Springer-Verlag. 